\title{
Optimising energy use in an existing commercial building: a case study of Australia's Reef HQ Aquarium
}

\author{
Sascha Thyer (D) Severine Thomas • \\ Craig McClintock $\cdot$ Michael Ridd
}

Received: 26 September 2016 / Accepted: 4 August 2017 /Published online: 6 September 2017

(C) The Author(s) 2017. This article is an open access publication

\begin{abstract}
Reef HQ Aquarium is a major tourism attraction in tropical North Queensland, Australia. In 8 years, a $50 \%$ reduction in grid electricity was achieved through targeted infrastructure investment, whilst growing the business. Initially, grid energy consumption was 2438 MWh per annum, with 490-kW peak demand and energy intensity of $1625 \mathrm{MJ} \mathrm{m}^{-2}$ year $^{-1}$ used on typical equipment such as HVAC (heating, ventilation and air conditioning), machinery, lighting and catering equipment. Savings of $13 \%$ were achieved in the first year by increasing indoor air temperature set-points by $1.5^{\circ} \mathrm{C}$ with no significant costs or impacts on occupant thermal comfort or worker productivity. Peak demand was decreased by $46 \%$ by upgrading the computerised building management system (BMS), HVAC, machinery and lighting; and by installing a 206-kW photovoltaic (PV) solar power system. This case study illustrates that (a) significant energy use reductions are possible at
\end{abstract}

S. Thyer $(\bowtie) \cdot$ S. Thomas

Reef HQ Aquarium (Great Barrier Reef Marine Park Authority), Townsville, QLD, Australia

e-mail: sascha.thyer@gbrmpa.gov.au

S. Thyer

College of Marine and Environmental Sciences,

James Cook University, Townsville, QLD, Australia

C. McClintock

McClintock Engineering Group Pty Ltd, Member of Engineers

Australia, Townsville, Australia

M. Ridd

College of Science and Engineering, James Cook University,

Townsville, Australia low cost; (b) capital investment in energy-efficient infrastructure can have short payback times and high direct and indirect benefits, particularly where equipment is ending its life. This study is unique as it examines how a commercial building with integrated chilled water thermal energy storage (TES) and a 3.2-ML chilled seawater aquarium system can be controlled by a BMS to optimise solar power to manage peak energy demand and also increase the utilisation of generated PV power in the absence of electrical battery storage. An interesting building is used to demonstrate efficiency methods with elements such as HVAC and lighting which usually consume over half commercial buildings' energy use.

Keywords Building retrofit - Energy efficiency . Thermal comfort $\cdot$ HVAC with chilled water TES $\cdot$ Solar PV

\section{Introduction}

In developed countries, the buildings sector (residential, commercial, and public) uses between 20 and $40 \%$ of final energy consumption (Perez-Lombard et al. 2008). In Australia, the buildings sector represents approximately $23 \%$ of Australia's total greenhouse gas emissions (Australian Sustainable Built Environment Council 2008). There is evidence that energy efficiency can have a positive effect on economic growth (Vivid Economics 2013) and reductions in commercial buildings energy use represent an opportunity to reduce global greenhouse gas emissions (Pitt and Sherry 2014; 
Levine et al. 2007). As most energy is consumed in existing buildings within the buildings sector, rapid enhancement of energy efficiency in existing buildings is considered essential for a timely reduction in global energy use (Ma et al. 2012). Total energy consumption within the Australian economy has been falling since 2011-2012 despite a growth in the economy, in part due to increases in energy efficiency (Department of Industry and Science 2015). However, more is achievable by focusing on existing infrastructure (Australian Sustainable Built Environment Council 2008; Biswas 2014). This work aims to bridge the gap between the demonstration of new energy efficiency models in scientific settings, and energy efficiency retrofit measures applied by an owner/manager in a real-world setting which takes into account the practicalities of an ageing commercial building and resourcing for retrofit actions.

This study examines an 8-year refurbishment of the Reef HQ Aquarium ('the Aquarium') which was built in 1987 and is the world's largest living coral reef aquarium. As the Australian Government's National Education Centre for the Great Barrier Reef, it is a major tourism attraction of tropical North Queensland, attracting over 140,000 visitors annually. The Aquarium is federally owned and funded and achieves greater than $80 \%$ operational cost recovery through ticket sales (and educational revenue). A suite of energy saving measures was instigated and implemented with the aim of reducing grid energy use by $50 \%$, from low-cost operational measures to major capital investment. Such a target has been shown to be theoretically possible (Ardente et al. 2011), but few case studies relate to older commercial facilities significantly reducing their energy use whilst remaining operational. Despite its specificity, the Aquarium has all major energy use categories of most buildings such as HVAC (heating ventilation and air conditioning), machinery, lighting, catering equipment, electronic equipment and domestic hot water. Worldwide, buildings' energy consumption can be up to $70 \%$ for HVAC systems and artificial lighting (Colmenar-Santos et al. 2013). The Aquarium is similar to most buildings in that the largest portion energy consumption can be attributed to HVAC. This study adds to work of others by examining the effect of changes to indoor temperature in a commercial building in a tropical location, on a broad range of subjects such as tourists, students and workers. This work is important as it has been noted by other authors that more studies are needed to quantify the impact of thermal comfort on productivity (Rupp et al. 2015).
Despite the excellent conditions for solar photovoltaic (PV) systems, in 2015, renewable energy generation accounted for only $15 \%$ of Australia's total energy generation, whilst the electricity supply sector accounted for $27 \%$ of Australia's energy consumption (Department of Industry and Science 2015). An increase in renewable energy systems throughout Australia is expected to reduce grid energy use, life cycle costs for energy generation, transport and transmission (Stoppato 2008; Epstein et al. 2011; Garnaut 2011). In 2011, the Aquarium installed the second largest (at that time) rooftop solar photovoltaic (PV) system in north Queensland, where conditions are geographically ideal. This study details the programming of a retrofitted building management system (BMS) to not only control lighting, machinery, the internal building environment and an HVAC system with integrated chilled water thermal energy storage (TES), but to also optimise the use of solar PV generation. Since HVAC energy demand in most buildings represents a high proportion of power demand and electrical battery storage for PV power remains expensive, this solution may represent a cost effect way to minimise battery storage.

The objective of this study is to examine the efficacy of the methods used for a comprehensive energy efficiency retrofit undertaken over many years by a commercial building owner/manager. Specifically, the study aims to answer the following questions: (1) can energy efficiency in an older building be achieved at low cost?; (2) were energy audits an effective measure to facilitate energy efficiency at the Aquarium?; (3) what was the impact of the Aquarium's retrofit actions on grid electricity consumption and what were the most effective measures?; (4) what was the impact of raising indoor temperature set-points?; (5) can a BMS controlling HVAC with integrated TES be used to optimise the use of dynamic power generation from a large solar PV system? This case study uses an interesting and unusual existing building (a public aquarium) to detail the technical steps taken for the energy efficiency measures undertaken, and it evaluates and compares a variety of energy conservation methods that were implemented, in a real-world setting. Many of these measures (like HVAC, which uses at least half the power in most commercial buildings) could be applied to many commercial buildings, public swimming facilities, and public aquariums. 


\section{Related work}

Although there is a significant body of work in the scientific literature on the benefits of energy-efficient retrofits, many case studies are outside the academic literature. Thus, more practical case studies are needed to demonstrate significant energy saving potential of building retrofits undertaken by building owners and managers to increase the level of confidence in potential retrofit benefits (Ma et al. 2012; Ardente et al. 2011). There are numerous theoretical studies focused on the energy analysis of public buildings (Ardente et al. 2011; Fiaschi et al. 2012; Steinfeld et al. 2011) and models to predict energy savings for buildings (Aljami 2012; Rysanek and Choudhary 2013; Woo and Menassa 2014) including those in tropical Australian climates (Rahman et al. 2010). Few studies currently report on other commercial and industrial buildings (Markis and Paravantis 2007), and formal targets, guidelines, tools and government regulation are still lacking for a large bulk of building stock (Australian Government, Department of Climate Change and Energy Efficiency 2012; New South Wales Office of Environment and Heritage 2016; Saddler 2015).

Whilst there is a large body of work describing the use of TES systems for demand-side management (see review by Sun et al. 2013), only two recent studies detail the impact of integrated control of PV and ice thermal energy storage using energy modelling tools (Wang and Dennis 2015; Sehar et al. 2016) and one described the use of surplus wind energy and thermal storage (Xydis and Mihet-Popa 2016). This study is unique as it examines an end-user-operated direct digital control (DDC) BMS that controls HVAC with integrated chilled water TES, and the chilling of a large 3.2-ML aquarium tank, in order to optimise solar PV energy generation use in the absence of electrical battery storage.

The International Performance Measurement and Verification Protocol 2012 (IPMVP®) (Efficiency Valuation Organisation 2012) is used in this study as the principal method for measurement and verification. Alternative methods are also available such as the ASHRAE Guideline 14 (ASHRAE 2014) and ISO 17741:2016 General technical rules for measurement, calculation and verification of energy savings of projects (International Organization for Standardization (ISO) 2014). The AS/NZS 3598 Energy Audit series (Standards Australia 2014) and ISO 50001:2011 Energy Management Systems (International Organization for
Standardization 2011) provide guidance on audits and energy management systems, respectively.

\section{Methods}

Building description

The Aquarium is located in the city of Townsville $\left(19.2577^{\circ} \mathrm{S}, 146.8238^{\circ} \mathrm{E}\right)$, which has a mean maximum summer temperature of $31.3{ }^{\circ} \mathrm{C}$ with an average relative humidity in summer of about $70 \%$ (Bureau of Meteorology 2015). The entire usable building space for the Aquarium, including service and outdoor storage areas, is ca. $5400 \mathrm{~m}^{2}$. Of this space, $2345 \mathrm{~m}^{2}$ is air conditioned and $775 \mathrm{~m}^{2}$ is covered by the two main Aquarium tank systems shown in Fig. 1 (ca. 4 million litres of chilled seawater in total). Most aquarium tanks are maintained below $28{ }^{\circ} \mathrm{C}$ for optimum marine life preservation and coral health.

\section{Main energy use categories}

Energy consumption at the Aquarium can be split into five key categories:

HVAC: (refrigeration and no central heating; the common HVAC acronym is used) cools public and office spaces during opening hours and night functions 365 days every year and cools $4 \mathrm{ML}$ of aquarium water as required and a $20-\mathrm{kL}$ chilled water TES.

Machinery: filtration pumps that operate continuously, compressors running sporadically (for wave machine and SCUBA diving) and a reverse osmosis system operating seasonally.

Lighting: standard room lighting, special display lighting and high-intensity lighting for corals and plants.

Café: catering equipment such as refrigerators, freezers, warmers, dish washer and chip fryers.

Other: passenger elevator, electronic and audiovisual equipment, computers, photocopiers, life support system monitoring devices, workshop tools, low flow pumps, small aquarium heaters (small winter heating requirement), ozone generators, and other ancillary aquarium tank devices. 
Fig. 1 Reef HQ Aquarium, view from above showing solar photovoltaic system and two large open-topped aquarium tanks

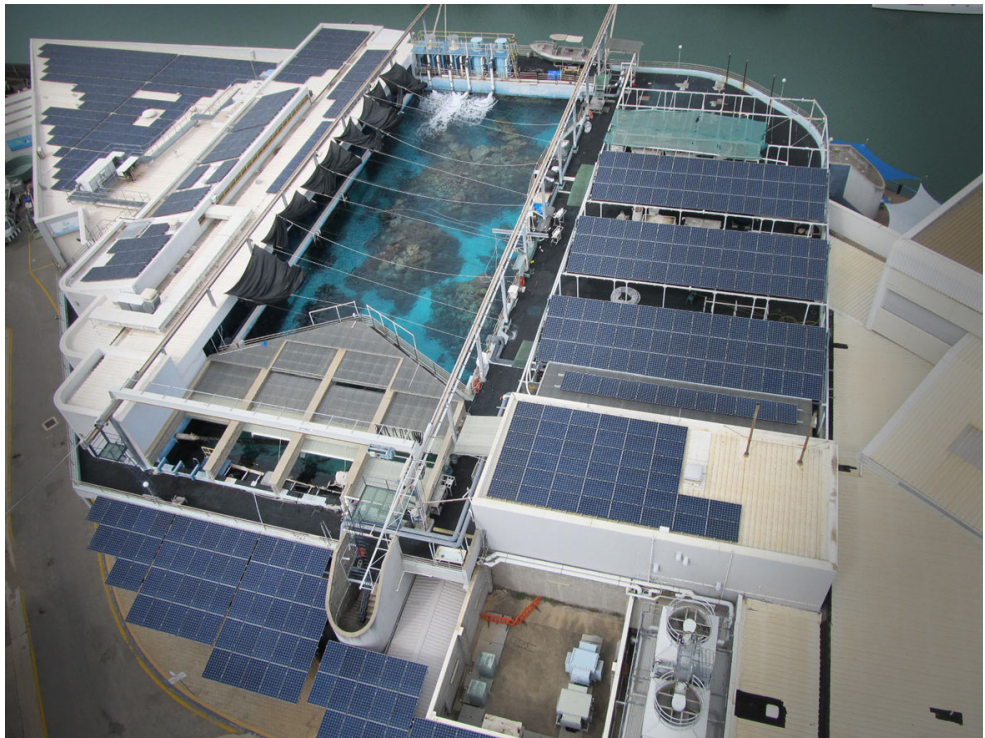

Energy use and costs data analysis

Year 0 (1 July 2005 to 30 June 2006 as per the Australian financial year) is set as the baseline year prior to the refurbishment period and subsequent financial years are numbered sequentially (year 1 to year 8 of refurbishment). All financial costs are in Australian dollars excluding GST (goods and services tax) as the Aquarium is GST exempt. Cost of electricity is the actual amount billed by the electricity provider (Ergon Energy). The modelled scenarios (i.e. estimate if no efficiency action was taken) are calculated using the energy provider's tariffs in each year.

The IPMVP® (Efficiency Valuation Organisation 2012) was used to analyse energy use and savings. IPMVP® Option C, Whole Facility, was used to compare the overall energy use between years, using half hour meter data provided by the grid energy provider. Separate energy-using elements were analysed with a combination IPMVP® Option A and B as described in detail in the 'Audits and retrofit process and energy reduction target' to 'Integrated rooftop solar PV system' sections. The proportional use of the five energy use categories was compared before and after refurbishment by taking point-in-time current transformer readings from electrical distribution boards in December of year 0 and year 8 . Energy meters (Crompton Instruments Integra 1630) provided kilowatt hour data on HVAC and cafe electrical loads. Where equipment was at the end of its life, only the additional cost of the energy-efficient measure against the businessas-usual replacement was factored into the payback times and overall savings (although total replacement cost is also shown in the results). Payback forecasts were calculated using electricity prices from the Australian Energy Market Operator (Frontier Economics Pty. Ltd. 2015). Labour rates were calculated using the average hourly rate of staff who would normally undertake the work. All financial costs include 5\% discount rate; for future years, electricity and materials costs include a 5\% escalation; and labour costs include a $3 \%$ escalation. A marginal abatement cost analysis was undertaken for five energy use categories and a sub-category 'Operational' (part of the 'HVAC and HVAC related' category) was also shown separately to examine the impact of measures with minimal cost. The conversion of kilowatt hour to carbon dioxide equivalent $\left(\mathrm{CO}_{2}\right.$-e) was calculated using the Australian Government National Greenhouse Account Factors (Department of the Environment, Commonwealth of Australia 2014). The emissions factor for 'scope 2' (emissions from directly burning fossil fuels) is $0.81 \mathrm{t} \mathrm{CO}_{2}-\mathrm{e} \mathrm{MWh}^{-1}$ for the Queensland (Australia) end user. If the emissions factor for 'scope 3' is also included, the value is $0.94 \mathrm{t} \mathrm{CO}_{2}$-e $\mathrm{MWh}^{-1}$. This factor is an estimate of indirect emissions from the extraction, production and transport and power loss through the distribution network. Both of these methods are applied in the 'Life cycle savings and $\mathrm{C}_{2}$-e avoided' section. 
Audits and retrofit process and energy reduction target

An internal energy audit was conducted in year 0 by the Aquarium's senior technical staff, with the aim of identifying areas of energy use inefficiencies. Six external firms were engaged in years 2 to 4 to investigate opportunities and feasibility of energy conservation proposals. The scope of each varied greatly. Using the combined audit reports, a wide range of potential retrofit actions were considered, cost-benefits were assessed, then the list of retrofit actions were narrowed and prioritised based on a balance of practical considerations such as (a) predicted power use reductions, (b) ease of implementation, (c) cost, payback times and funding arrangements, (d) internal versus external expertise and labour requirement, (e) other benefits aside from energy minimisation and (f) impacts on the visitor experience or disruptions to the animal life support systems. Assessment of possible energy use reduction following the internal audit led a reduction target of $50 \%$ over 5 years from year 1 .

The main drivers for energy use reduction initiatives at the Aquarium were a willingness to support the use of new high-efficiency equipment that underpin environmentally sustainable business practices (Great Barrier Reef Marine Park Authority 2007), economic pressure (rising electrical prices) and concerns about the impacts of climate change on the business and the Great Barrier Reef. Conversely, prior to 2005, relatively low electricity prices and limited availability of high-efficiency equipment fostered a culture of low capital investment and minimal focus on life cycle costs of equipment. A Demand Management Pilot Programme offered by the local electricity supplier Ergon Energy provided an additional incentive and formalised the focus on reducing peak power demand. This including a financial incentive for every kilowatt of peak power demand reduced. The Reef HQ Aquarium agreed to aim to reduce its $490-\mathrm{kW}$ peak power demand by $230 \mathrm{~kW}$. Ergon Energy engaged a consultant to measure the peak energy demand savings for the demand management programme years, and took into account historical weather data and adjusted for changes in HVAC loads. The Ergon Energy meter data was analysed by the consultant using the IPMVP® Option C, Whole Facility, Eq. 1B (Efficiency Valuation Organisation (EVO) 2012). This analysis examined only the peak demand only over a 6-month period (peak demand summer period) from August 2012 to February 2013, against the baseline peak energy.
Audit benefits were measured by: (1) whether the reports were of a quality that could be used for funding proposals; (2) new and innovative content (i.e. not already proposed by Aquarium staff); (3) the volume of recommendations taken up by the Aquarium with good outcomes and (4) how the models in the reports compared to actual outcomes for measures taken up.

Indoor temperature changes and thermal comfort survey

In year 0, all AHUs were set to cool the Aquarium space down to $23.0{ }^{\circ} \mathrm{C}$ throughout the year, at $60 \%$ relative humidity and 0.12 to $0.26 \mathrm{~m} \mathrm{~s}^{-1}$ air flow $3 \mathrm{~m}$ away from ducted air vents. Early in year 1 , the indoor temperature set-points were raised by $0.2{ }^{\circ} \mathrm{C}$ increments over 3 months until all air-handlers were set at $24.5^{\circ} \mathrm{C}$. Half hour energy use was measured for the year before and after the change and routine visitor surveys were collected and reviewed for the year preceding (670 surveys) and following (970 surveys) the set-point change. No questions related directly to thermal comfort, but comments relating to infrastructure and different aspects of comfort in the facility were routinely received in an open field in the survey. Visitation during the year before and after the change was measured through ticket sales and data retrieved from a computerised point of sale system (SwiftPOSTM software). Aquarium facilities staff reported that they had received some complaints from staff about indoor temperature initially, but these complaints diminished over time (anecdotal evidence). The suggestion was that occupants may have adapted to a higher temperature over time. For this study, the anecdotal evidence that the impact of the change was minimal was tested in May 2016, by examining the impact of an indoor temperature change on comfort and productivity using a thermal comfort survey. The survey simulated the $1.5^{\circ} \mathrm{C}$ temperature change undertaken in year 1 , and recorded the thermal comfort response on all categories of human occupants (visitors, Aquarium staff and volunteers and staff from the adjacent Great Barrier Reef Marine Park Authority (GBRMPA) offices). For worker occupants, selfassessed productivity whilst in the Aquarium was also examined. The indoor set-point was set at 23 and $24.5^{\circ} \mathrm{C}$ on alternate days for 2 weeks (14 days) and all staff and volunteers were encouraged to complete the survey twice on two different set-point days, which were arbitrarily identified as a 'green day' and a 'yellow day' to avoid potential bias. The questionnaire asked: (i) 
one's clothing level (light, moderate and high); (ii) thermal sensation (cold, cool, neutral, warm, hot); (iii) and thermal comfort (very uncomfortable, moderately uncomfortable, slightly uncomfortable, slightly comfortable, moderately comfortable, very comfortable).

The statistical interpretation of the survey results was undertaken using the Statistica 13 package (StataCorp 2013), and scales of comfort and productivity were converted to a numerical scale. An assessment of workers' productivity was obtained by workers selfassessing their efficiency at the time of the survey in relation to their average efficiency (clearly above, slightly above, at my average efficiency, slightly below, clearly below) (Kekäläinen et al. 2010). An independent samples $t$ test was used to assess the statistical difference in responses at the two different temperature set-points, using a significant level of $p<0.05$. For data that was not normally distributed, and could not be transformed to achieve normality, a non-parametric Mann-Whitney $U$ test was undertaken. A factorial ANOVA was undertaken on the comfort responses with the two factors being temperature (either 23 or $24.5^{\circ} \mathrm{C}$ ) and respondent type (Reef HQ staff, volunteer, GBRMPA staff and visitor) followed by Tukey HDS test. Air temperature was logged during the survey period by the BMS (using Reliable Controls ${ }^{\mathrm{TM}}$ SPACE-Sensor Temperature), averaging temperature from three sensors for each AHU area. Outside humidity and temperature were also logged by the BMS. The airflows through the AHU air vents were checked to ensure they were consistent with the commissioned data for the HVAC system.

\section{HVAC, TES and BMS}

HVAC consumed about $50 \%$ of energy use in year 0 and was highlighted in the internal audit and a technical audit as having significant opportunity for efficiency gains. The original HVAC system consisted of two aircooled chillers (total $600-\mathrm{kWr}$ power) and two alternating 30-kW pumps running continuously. The technical audit reported poor circulation around the air-cooled chillers, maintenance issues, inefficient and unbalanced hydronic system configuration, inefficient air side systems (deviating up to $30 \%$ from design values) and a negative building pressure, drawing excessive hot outside air into the air-conditioned space; the chillers were inefficient with an average system coefficient of performance (COP) of 2.4, and excessive start and stop of the chillers (20 times per night). Although the system was only 9 years old with a usual lifespan of $12-15$ years, the hot, humid and corrosive aquarium environment combined with a high-load and inefficient design had left it in poor condition, leading to a replacement of the chilling plant itself. A state-of-the-art, modular, highefficiency water-cooled multi-chiller solution was installed with a long predicted lifespan. Three Hitachi twin screw-type chillers (RCUP67WUZ model; continuous digital control between 15 and $100 \%$; capacity $236 \mathrm{kWr}$; 4.55-5.86 efficiency at 100\% load) and multi-pump system were chosen to allow for redundancy and adjustment to a minimum load and for peak power demand management. A base load $20 \mathrm{~kL}$ chilled water TES tank was installed to decouple the primary and secondary pumping groups and prevent excessive chiller starts. The TES operating range is $6-15^{\circ} \mathrm{C}$ with a temperature differential of $9{ }^{\circ} \mathrm{C}$. Previously, the chilled water system would cool the building as well as $4 \mathrm{ML}$ of seawater in the exhibits simultaneously day and night. The energy use efficiency achieved by the upgrade of the HVAC and addition of the TES tank was assessed by quantifying the increase in chillers average COP, the average number of chiller starts per night, the reduction of HVAC power consumption and effect on peak demand.

Heat load on the HVAC system was reduced with (a) replacement of lights and pumps with more energyefficient versions; (b) a reflective roof coating applied to the corrugated roof and (c) replacement of ca. $88 \mathrm{~m}^{2}$ of single glazing with deteriorated low-quality window tint with double-insulated argon-filled low-e glazing (Viridian Glass argon-filled insulated glass unit with EVantage $^{\mathrm{TM}}$ tint). The measures could not be isolated from each other, so they were consolidated into the category 'HVAC and HVAC related' whose consumption could accurately be measured through HVAC energy metering in the BMS.

Prior to refurbishment, the HVAC was controlled by a simple direct digital control (DDC) system that was underutilised to only control time schedules, the proportional flow of chilled water to the air handling units (AHUs) and stop/start two air-cooled chillers and two chilled water pumps. A more sophisticated but end-userfriendly DDC system was installed using ASHRAETM standard BACnet ${ }^{\mathrm{TM}}$ protocol, incorporating fully programmable peer-to-peer building controls allowing sophisticated control of chillers and associated equipment, AHUs, the internal environment, the integrated TES, aquarium tank chilling and peak power demand from 
the grid through load shedding. The BMS also monitors overall power use and power use of selected systems and equipment and can control and schedule power loads of other power using systems such as aquarium life support systems. No export of power back to the grid is allowed by the energy provider and as an additional precaution they imposed (see the 'Integrated rooftop solar PV system' section) that a mandatory grid protection device (Woodward MC4A grid protection relay) must shut down inverters to prevent grid demand less than $8 \mathrm{~kW}$. Due to the high cost of finer control, the protection device shuts down in $50-\mathrm{kW}$ sections. To prevent inverter shutdown and potential wastage of solar PV power, more complex algorithms were added to the BMS to manage the uncertainty of solar PV generation within user-defined thresholds, by limiting chilling or by automatically designating chilling priorities between the AHUs, aquarium tanks and TES. Within user-defined thresholds, it can bring forward a chilling requirement beyond the optimal aquarium tank set-points to maximise the use of solar power or delay the chilling requirement when the chilling requirement is not critical to manage peak demand. The aim is to reduce the chilling requirement in peak energy demand periods when the PV generation drops off, and ensure minimal wastage of PV generation. The system uses classic local-loop control techniques that consist of on-off control of pumps and chillers and proportional-integral-derivative (PID) feedback control of chilled water through valves and with rule-based algorithms with 'If-Then rules' and 'Fuzzy-logic control' to prioritise chilling and energy management (see Yu et al. 2015 for a review and description of control strategies for buildings with TES).

Using the solar power inverter data, which is collected in 15-min intervals, the PV generation wastage was estimated by totalling the estimated lost power from each grid protection event (i.e. the amount of surplus power generated) for 1 year from September 2015. The data is not a direct measure of surplus power (rather an estimate of likely output in the absence of grid protection event) as the wasted power could not be precisely calculated for this study.

An algorithm to delay discharge of the TES was introduced in 2016 and analysed for 7 days in September 2016 to determine if the chilling load could be maintained above the threshold that would trigger the grid protection device. The savings in power were compared to the cost of storage of electrical power using an electrical battery storage solution.
Machinery and lighting energy efficiency improvements

Aquarium pumps and compressors rated up to $37 \mathrm{~kW}$ used approximately $40 \%$ of the power in year 0 . Energy use audits reported that purchasing of machinery was historically based on capital cost, quality and durability in the corrosive Aquarium environment, but not on power consumption, resulting in many pumps being over-sized for their application. The filtration systems were reviewed by Aquarium staff and an external technical audit. Subsequently, filtration piping was redesigned to maximise efficiency and pumps and associated motors were replaced with more efficient models. The reverse osmosis machine used to remove freshwater from the Coral Reef Exhibit during heavy monsoonal rains used high-pressure, high-energy use pumps. Since this system was at the end of its life, it was replaced with a high efficiency model. For static load equipment such as pumps, point-in-time load readings from distribution boards were recorded by an electrician before and after the retrofit actions. The kilowatt - hour energy use of individual equipment and systems was then calculated using average duration of operation per day (most pumps run continuously).

Dilapidated skylights and some high-intensity flood lights were replaced with engineered skylights (Solatube ${ }^{\mathrm{TM}}$ ) which minimise infrared light. Plasma flood lights and high-intensity LED lights replaced inefficient metal halide lights and general lights were replaced with LED lights. The fixed electrical consumption of lights was calculated using the manufacturer's specified power consumption multiplied by the time schedule or average hours per day the equipment was in operation.

Two of the energy-efficient audit reports suggested that air leaks on systems using compressed air were leading to energy wastage, and subsequently, the wave machine compressor system (part of the life support system for the main Coral Reef Exhibit) was adjusted to address inefficiencies and leaks. The energy consumption of the wave machine was monitored in the BMS.

Integrated rooftop solar PV system

A 206-kW rooftop solar PV power system (shown in Fig. 1) was built to minimise peak power demand, overall grid power use and switch to a sustainable 
source of power generation. The system was sized within the limitations of available roof space, budget and the Aquarium's daytime power needs. A feasibility study of a large solar power system at the Aquarium predicted a $4.6 \mathrm{kWh}$ per day per kilowatt of solar power installed (it modelled a $148-\mathrm{kWp}$ system). The solar PV feasibility models were compared to actual cost benefit data, and the actual performance and output of the system. Solar generation data is logged automatically using energy data loggers (SMA Solar Technology WebBox ${ }^{\mathrm{TM}}$ ). For the purpose of calculating the energy saving of the solar PV system, a scenario without the solar PV was modelled, by adding the solar generation to the grid energy use, to determine the peak energy load in this scenario.

\section{Results}

The $50 \%$ target was almost achieved by the end of year $7(46 \%)$, and exceeded in year $8(52 \%)$, shown in Fig. 2. The sequence of implementation was based on the prioritisation criteria described in the 'Audits and retrofit process and energy reduction target'section and is shown in Table 1 and Fig. 2.

Total energy consumption

Figure 2 shows the impact on power use of the main retrofit elements. For year 0 , the overall baseline grid energy consumption for the whole site was $2438 \mathrm{MWh}$ and peak demand was $490 \mathrm{~kW}$ (551 kVA with an average power factor of 0.89). Baseline energy was $22 \mathrm{kWh}$ visitor $^{-1}$ year $^{-1}$ (energy use per visitor) and $1625 \mathrm{MJ} \mathrm{m}^{-2}\left(451 \mathrm{kWh} \mathrm{m}^{-2}\right.$ year $\left.{ }^{-1}\right)$ at a cost of $\$ 211,725$ year $^{-1}$ (2006 tariffs). The cost of adopting no energy-efficient measures is illustrated by the point 'Adjusted baseline power use at 2015 price' in Fig. 2. It shows the actual baseline power use of $2348 \mathrm{MWh}$ year $^{-1}$ plus $286 \mathrm{MWh}$ year $^{-1}$ associated with growth of Aquarium assets and animal life support systems. This includes $14 \mathrm{MWh}$ year ${ }^{-1}$ for extra air conditioning split systems and new exhibit cooling, $211 \mathrm{MWh}$ year $^{-1}$ for additional pumps and $61 \mathrm{MWh}$ year $^{-1}$ for chilling the main aquariums by an extra $1.5^{\circ} \mathrm{C}$ in the hotter months. Other factors probably added to energy consumption including increased visitation, a new 60-person conference facility, additional lighting and new electronic equipment for new exhibits and any increase in ambient air or sea surface temperatures. It was not possible to obtain precise data for these factors so they are not included in the baseline power adjustment. In 2015, the adjusted energy use would have cost $\$ 500,808$ year $^{-1}$ (the unadjusted baseline energy use would cost $\$ 471,610$ year $^{-1}$ ). Overall grid energy consumption was reduced to $1160 \mathrm{MWh}$ by year 8 representing an energy intensity of $773 \mathrm{MJ} \mathrm{m}^{-2}$ or $9 \mathrm{kWh}$ visitor $^{-1}$ year $^{-1}$.

Total cost versus total savings and distribution of energy use categories

Table 1 summarises the efficiency actions and capital investment that led to a $52 \%$ reduction in grid supplied power use by year 8 (that was maintained at $50 \%$ in the following year). The $\$ 374,646$ saved in electricity and maintenance costs in year 8 represents $10 \%$ of the total Aquarium operating expenditure for that year. Between years 0 and $8, \$ 1.7 \mathrm{M}$ was spent on energy efficiency measures and $\$ 1.25 \mathrm{M}$ was saved. These savings are significant given that the majority of the capital investment was expended in years 6,7 and 8 on the two largest initiatives: HVAC upgrade and solar power station. Complete payback for all measures should be achieved in 2017. The saving calculations include the following: avoided electricity costs; solar power generation; large-scale generation certificates (LGCs) created with the Australian Clean Energy Regulator (using LGC market price of \$75/MWh in February 2016 (Green Energy Markets 2016)); decreased labour cost due to reduced maintenance; and the avoided cost of spare parts and replacement pumps.

Figure 3 shows the shift in the distribution of power use between the main categories between years 0 and 8 . HVAC and machinery represented a total of $95 \%$ of the energy use prior to the refurbishment period. The HVAC upgrade and adjustments significantly reduced its energy use relative to other categories. The dramatic reduction in pumping energy made for existing equipment was somewhat offset by new pumps and enhanced life support systems. The category 'Other' increased noticeably due the increase in digital displays, projectors, ozone generators, UV sterilisers and computers (see the 'Discussion' section). 


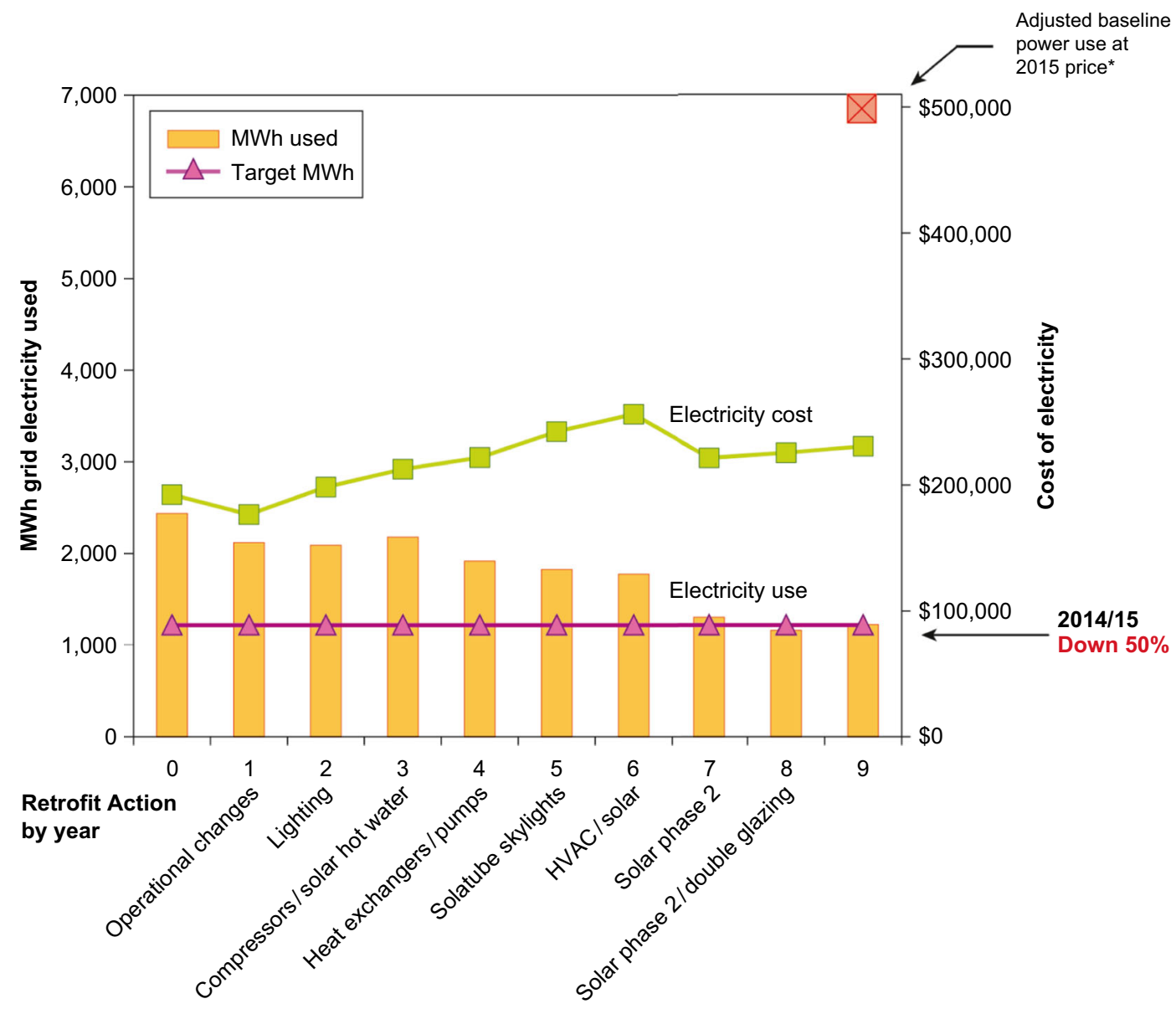

Fig. 2 Power use (primary y-axis) and power cost (secondary yaxis) per year ( $\mathrm{x}$-axis), and showing the main retrofit actions by year (x-axis).The asterisk indicates calculation included the

Audits and minimal cost operational changes

The internal audit highlighted some energy inefficiencies that were addressed immediately (shown in Table 2), leading to a $13 \%$ reduction in energy use for a cost of $\$ 6500$ in year 1. Of the seven external audits, two were funded from the Aquarium's operational funding, two from other GBRMPA sections part of wider audits and three associated with the Demand Management Pilot Programme (so only the exact cost the reports funded by the Aquarium could be reported in Table 1). Three of the reports focused on workshops with Aquarium staff to synthesise and document existing in-house information. Four audits provided highly specialised advice on technology, budget planning, modelling and key long-term strategies and $\mathrm{M} \& \mathrm{~V}$ with enough detail and quality to be used in baseline power adjustment for additional power use of additional equipment. See the 'Total energy consumption' section for more detail

future asset life cycle planning. The most expensive reports did not lead to the most significant benefits.

HVAC upgrade and control

Indoor temperature adjustment

In year 1 , the indoor temperature was raised by $1.5{ }^{\circ} \mathrm{C}$ and the energy savings are included in the $13 \%$ reduction shown in Table 1. General satisfaction surveys of the Aquarium collected in years 0 and 1 reflected no change in the number of comments on visitors' thermal comfort and there was a steady rise in visitation from 109,000 in year 0 to 140,000 in year 9 .

The year 9 thermal comfort survey supports the anecdotal evidence that there was no significant difference in thermal comfort of occupants as a result of the indoor temperature change. During this survey period, indoor 


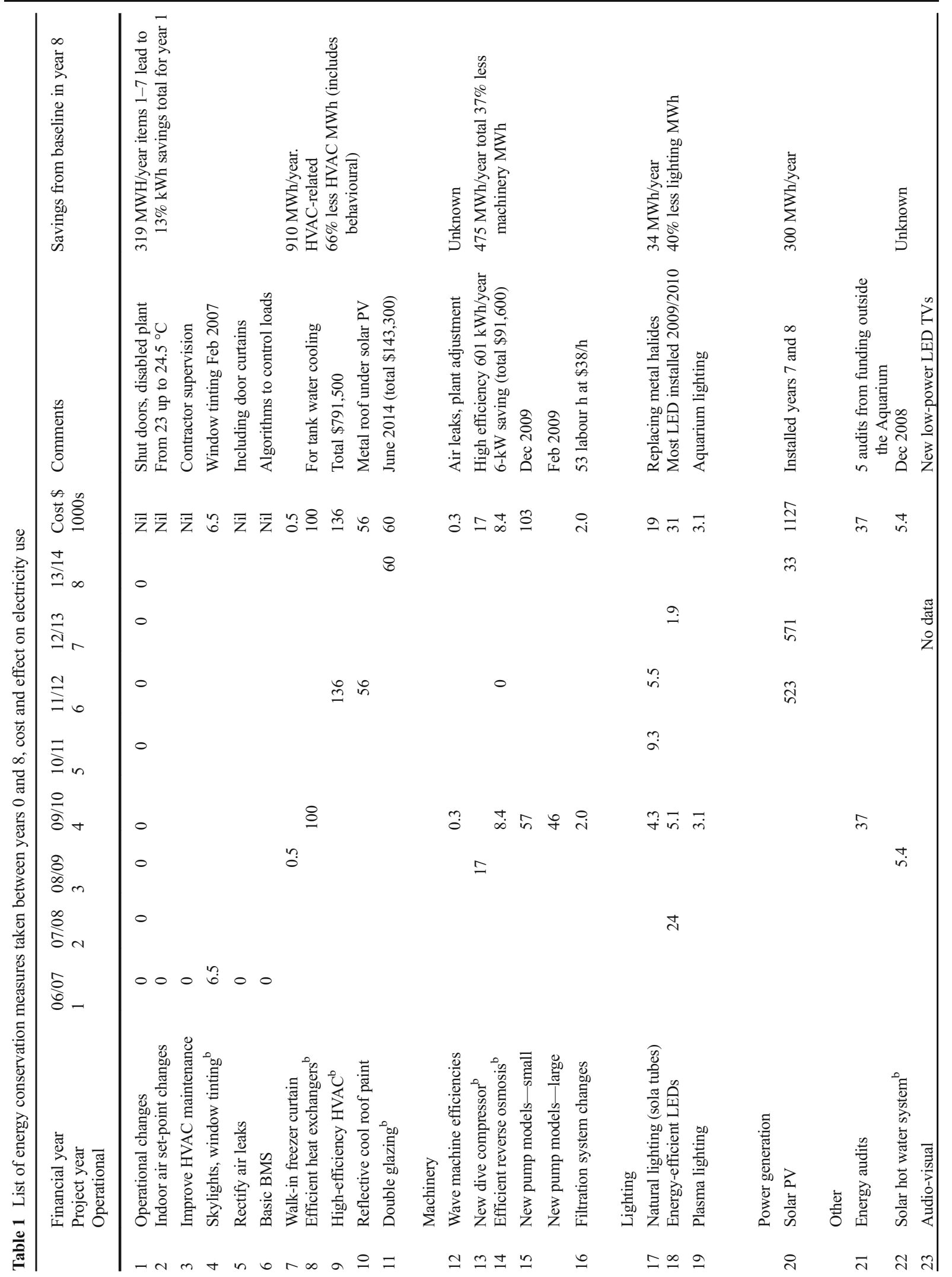


air temperature remained relatively stable for survey areas at the two set-points: between 23.0 and $23.6^{\circ} \mathrm{C}$ for the $23{ }^{\circ} \mathrm{C}$ set-point, and between 24.5 and $25.1{ }^{\circ} \mathrm{C}$ for the $24.5^{\circ} \mathrm{C}$ set-point. Indoor relative humidity varied between 55 and $65 \%$ (outdoor relative humidity $77-$ $92 \%$ ), due to large volume of evaporation from opentopped aquariums. Fixed airflows were confirmed at 0.12 to $0.26 \mathrm{~m} \mathrm{~s}^{-1}$ at $3 \mathrm{~m}$ from the ducted air vents. For the 552 surveys collected, $88 \%$ stated clothing as light and more than $80 \%$ rated thermal comfort as comfortable under both set-point conditions, consistent with ASHRAE 55 Standard Predicted Mean Vote and Predicted Persons Dissatisfied (PMV-PPD) for five parameters (clothing level, activity, humidity, temperature, airspeed) at each set-point using the ASHRAE Standard 55-2010 Thermal Comfort Tool (Huizanga 2010).

For all statistical tests applied to the data in Figs. 4 and 5 , the significance threshold was set at 0.05 . Figure 4 shows the mean comfort score declined from 4.91 ( $\mathrm{SD}=1.13, n=286)$ to $4.74(\mathrm{SD}=1.19, n=266)$ as temperature increased. An independent samples $t$ test of these data showed no significant difference in the comfort data for the two set-points $(t(550)=1.74, p=0.082)$. Since the data was not normally distributed nor could be transformed to achieve normality, a non-parametric Mann-Whitney $U$ test was undertaken. This test confirmed that the comfort rating at $23{ }^{\circ} \mathrm{C}($ median $=5)$ was not significantly different to that at $24.5^{\circ} \mathrm{C}($ median $=5)$, $U=34,864, p=0.076, r=0.08$.

Figure 5 shows data for the 233 respondents who were in Reef HQ for the purpose of work. It was found that the mean productivity score increased marginally from $3.127(\mathrm{SD}=0.686, n=118)$ to 3139 ( $\mathrm{SD}=0.634$, $n=115$ ) which was confirmed to be statistically insignificant by a $t$ test of the normally distributed dataset $(t(231)=0.139, p=0.89)$. A Mann-Whitney test confirmed that the productivity rating at $23{ }^{\circ} \mathrm{C}($ median $=3)$ was not significantly different to that at $24.5^{\circ} \mathrm{C}$ (median $=3), U=6717, p=0.86, r=0.04$. A factorial ANOVA undertaken on the comfort responses with the two factors being temperature (either 23 or $24.5^{\circ} \mathrm{C}$ ) and respondent type (Reef HQ, Volunteer, GBRMPA and visitor) showed the main effect of temperature yielded an $F$ ratio of $F(1544)=0.86, p=0.35$ confirming that the effect of temperature was not significant. The main effect for respondent type yielded an $F$ ratio of $F(3544)=4.51, p=0.0039$ showing that responses between respondent types were significantly different. The interaction effect was non-significant, with an $F$ 
Year 0 (2006)

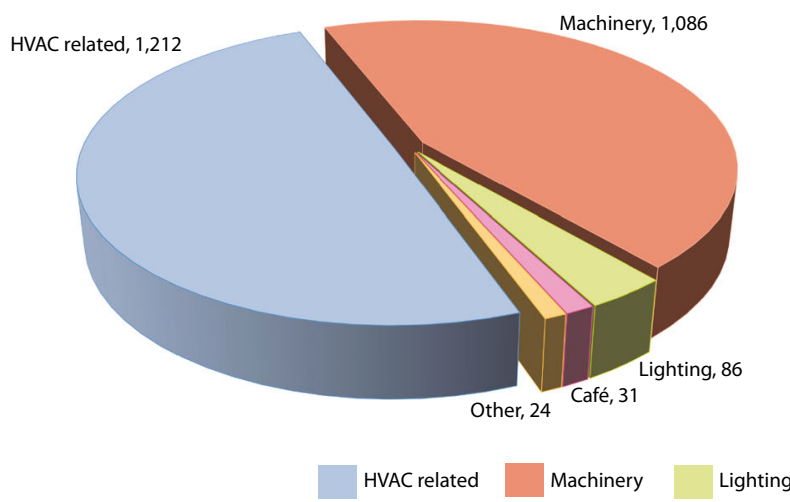

Fig. 3 Distribution of electricity consuming categories before (left) and after (right) the refurbishment period, shown in MWh. The baseline in 2006 is the actual baseline ( $2438 \mathrm{MWh})$. The total energy used in 2014 (1421 MWh) includes the grid energy

ratio of $F(3544)=0.45, p=0.716$. A Tukey HSD test showed that the GBRMPA staff and the visitors, who reside in the Aquarium for a relatively short period of time, showed the greater change in comfort perception to Reef HQ and volunteers who generally reside in the Aquarium all day. No clear conclusions could be drawn from this result.

Major upgrade of the HVAC system including TES and BMS

The TES tank provides up to $4 \mathrm{~h}$ of thermal storage and it minimised chiller starts from ca. 20 per $24 \mathrm{~h}$ day all year, to 3-6 per $24 \mathrm{~h}$ day (depending on the season). The system also has significantly greater efficiency, with an average 4.8 COP for the new chillers and variable speed drives on the pumps that allow for the most efficient use of pumping power.
Year 8 (2014)

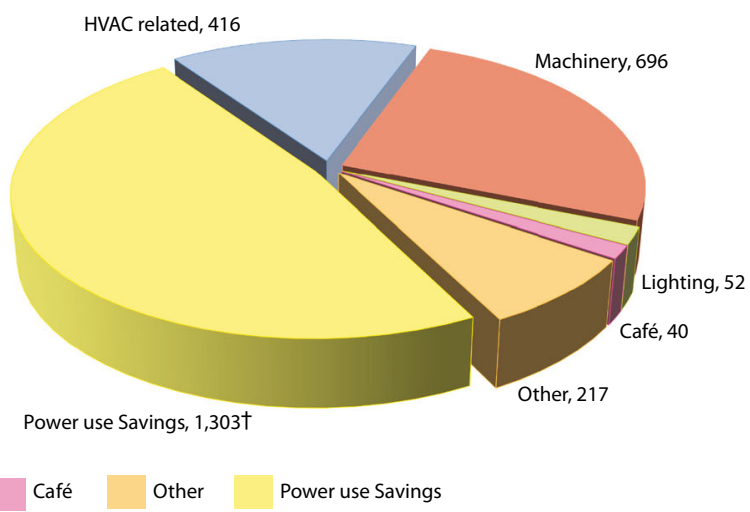

$(1160 \mathrm{MWh})$ and solar power (260 MWh). Dagger indicates that savings in 2014 take into account the adjusted baseline ('Total energy consumption' section)

The system is able to run on only one of the three chillers for approximately 7 months of the year. The BMS control of the TES tank allows the load to be spread more efficiently by prioritising cooling to the building and then redirecting any spare cooling capacity into the TES tank and to aquarium tanks. It shifts and delays chilling loads which compensate for unpredictable energy generation. User-defined trigger points for the process allowed trial and error determination of the correct set-points that allow for fast changes in PV generation (e.g. on a partly cloudy day) and slower valve response times. The method of chilling of the large 4-ML aquariums (timing and degree of chilling) has a significant effect on the peak demand. Tests showed that without intervention of the BMS algorithms, chilling of the Reef Tank alone leads to a $100-\mathrm{kW}$ higher peak demand, under minimal PV generation conditions.

Table 2 Issues identified by the internal audit in year 1 and subsequent operational measures taken

\begin{tabular}{lllllll}
\hline $\begin{array}{l}\text { Audit } \\
\text { reference }\end{array}$ & $\begin{array}{l}\text { Quality acceptable to } \\
\text { funding applications }\end{array}$ & $\begin{array}{l}\text { New measures or } \\
\text { technical detail } \\
\text { suggested }(\%)\end{array}$ & $\begin{array}{l}\text { New measures } \\
\text { adopted }(\%)\end{array}$ & $\begin{array}{l}\text { Report models } \\
\text { accurate against actual }\end{array}$ & $\begin{array}{l}\text { Outcomes for new } \\
\text { measures adopted }\end{array}$ & $\begin{array}{l}\text { Audit cost } \\
\text { (all but D paid } \\
\text { for by others) }\end{array}$ \\
\hline Internal & No & 100 & 100 & n/a & Good & $\$ 0$ \\
A & No & 20 & 10 & Partly & Poor & None \\
B & No & 0 & 0 & n/a & None & $\$ 10,000$ \\
C & No & 0 & 0 & No & Good & $\$ 42,0000$ \\
D & Yes & 30 & 30 & Mostly & Good & $\$ 27,000$ \\
E & Yes & 100 & 100 & Yes & Good & $\$ 10,000$ \\
F & Yes & 100 & 100 & Yes & & $\$ 10,000$ \\
\hline
\end{tabular}


Fig. 4 Mean comfort rating as a function of indoor temperature. Numerical scale in brackets $(\mathrm{x}$ axis)

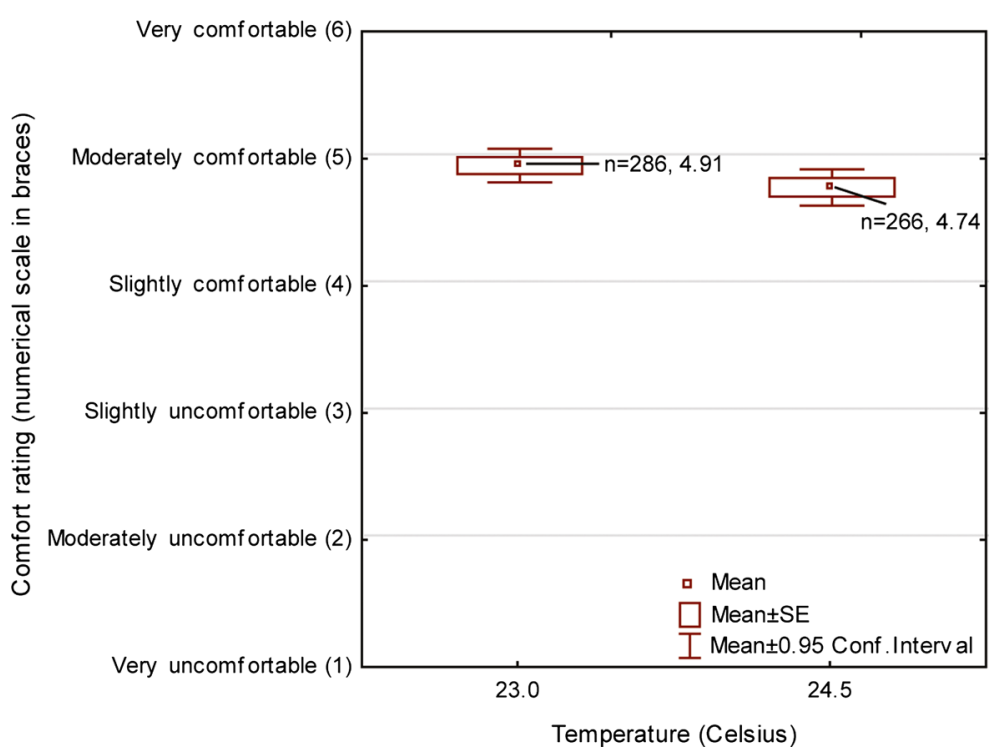

When the energy supplier's mandatory grid protection trigger point is reached $(8 \mathrm{~kW})$, the grid protection device shuts down the solar power system in sections to prevent any export of power to the grid. PV inverter data showed these events occurred frequently (numerous times a week or up to three times a day) and the power wasted is estimated ca. $25,000 \mathrm{kWh} /$ year or approximately $7.6 \%$ of the total yearly yield. In the absence of the algorithm to directly prevent discharge of the TES (as previously described), the algorithm to prioritise Reef Tank cooling during peak PV generation periods (the 'HVAC, TES and BMS'section) was observed (in the hotter period between October and April 2016). The algorithm was regularly activated (2 to 6 times per week) and showed that the occurrence and duration of the TES discharge could be minimised with only occasional discharges during PV generation hours leading to grid protection device activation. The PV wastage and wastage avoided could not be precisely quantified, but it was observed that the algorithm was activated 4-6 times per week during the months that Reef Tank cooling was required, indicating that the algorithm was regularly storing cooling energy that would otherwise be wasted.

The Reef Tank cooling algorithm is only used in the summer months when the tank temperature rises beyond the $27{ }^{\circ} \mathrm{C}$ set-point. Consequently, analysis of the data for
Fig. 5 Mean self-assessed productivity rating as a function of indoor temperature. Numerical scale in brackets ( $\mathrm{x}$-axis)

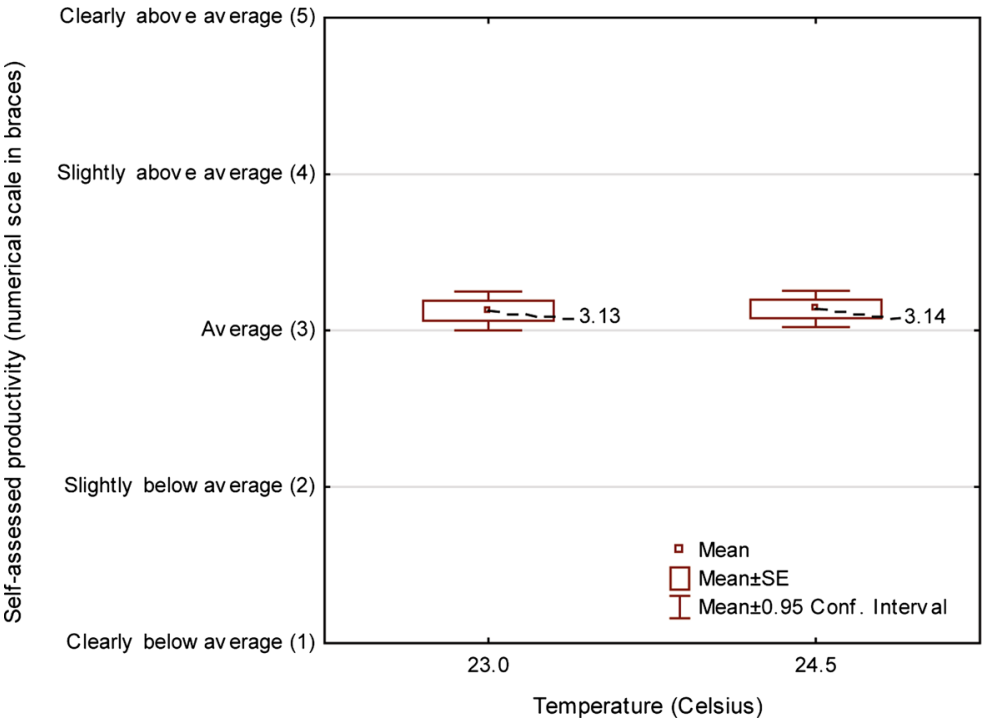


August 2016 (cold month with no tank chilling) with no BMS intervention indicated ca. $2700 \mathrm{kWh}$ power wasted with 25 occurrences for the month. The algorithm to delay discharge of the TES was introduced and analysis of 7 days in September 2016 showed that the algorithm was able to maintain the load above the threshold that would trigger the grid protection device. The algorithm to prevent discharge of the TES was triggered every day that week, and no activation of the grid protection device was recorded. Whilst more data is required to quantify the full impact of this measure through the seasons, we can conclude that it is possible to directly prevent the TES from discharging at its usual temperature set-points to avoid activation of the grid protection device, which avoids wastage of surplus PV generation and optimises HVAC use. No data is yet available for the combination of the Reef Tank cooling algorithm and the delay of TES discharge algorithm. This combination may avoid all PV generation wastage.

A budget estimate for supply and installation 91kWh bi-directional UPS (ininterruptable power supply) battery system using lithium batteries, all components included is ca. $\$ 200,000$. This could accommodate 25,000 kWh per year of energy storage.

For the glazing, only manufacturer's data was available that states the double glazing $u$ value is $2.7 \mathrm{~W} \mathrm{~m}^{-2}$ compared to $5.8 \mathrm{~W} \mathrm{~m}^{-2}$ for the single-glazed panels (no direct impact data available).

\section{Lighting and machinery energy efficiency} improvements

Total lighting power use was reduced by $40 \%$ from the baseline power use (Table 1), representing $34 \mathrm{MWh}$ year ${ }^{-1}$. In total, power use for machinery (all pumps except HVAC pumps) was reduced by $37 \%$ from the baseline, and a total of $475 \mathrm{MWh}_{\text {year }}{ }^{-1}$. Table 3 shows comparative life cycle costs of the existing relatively cheap pump model used for the small aquarium tanks substituted with a very high quality and efficiency model (overall $3.5 \%$ reduction in electricity consumption). Further, a total of six $37-\mathrm{kW}$ pumps were modified or replaced, and associated piping systems designed to optimise efficiency. In one example, a $37-\mathrm{kW}$ pump motor (on a variable speed drive, but running very inefficiently) was replaced with a $4-\mathrm{kW}$ motor for the same flow resulting in overall power savings of $3.5 \%$ from the baseline at a cost of $\$ 1500$ ( $\$ 9840$ saved on the electricity bill in the first year, payback time of 2 months). Prior to 2010, 15 metal submersible pumps $(240 \mathrm{~V})$ used for water circulation in the 3.2-ML Coral Reef Exhibit were inefficient and had maintenance issues and safety concerns. A replacement low-voltage, carbon-fibre plastic composite pump model saved $34 \mathrm{MWh}$ year ${ }^{-1}$ (1.5\% of baseline power) and $\$ 10,000$ per year in spare parts, labour and anodes to avoid pump corrosion. The overall energy savings for 'special machinery' were minimal and highly seasonal.

\section{Integrated rooftop solar PV system}

The solar feasibility study projected a $4.6 \mathrm{kWh}$ per day per kilowatt peak, slightly lower than the $4.34 \mathrm{kWh}$ per day per kilowatt peak measured for 2015 . This is probably due to a larger solar PV system than originally planned being installed (206 kW and not $145 \mathrm{~kW}$ ), resulting in the suboptimal location of some panels (resulting in occasional shading) and the effect of the grid protection device. The overall system performance exceeded expectations and performed equal to commissioning 3 years later and no maintenance costs in the first 4 years. The predicted system cost was $\$ 5.50$ per
Table 3 Comparative life cycle cost of small aquarium pumps. Figures have been validated with the actual costs for 7 years

\begin{tabular}{lll}
\hline $\begin{array}{l}\text { Replacement of 46 small aquarium pumps with 33 higher } \\
\text { quality pumps }\end{array}$ & $\begin{array}{l}\text { 'Cheap' } \\
\text { model }\end{array}$ & $\begin{array}{l}\text { Energy-efficient } \\
\text { model }\end{array}$ \\
\hline $\begin{array}{l}\text { Capital expenditure over 10-year life } \\
\text { Total labour cost for breakdown maintenance for 10-year life }\end{array}$ & $\begin{array}{l}\$ 42,262 \\
\$ 162,602\end{array}$ & $\$ 87,960$ \\
$\begin{array}{l}\text { Total life cost of replacement parts/pumps for 10-year life } \\
\text { Total life energy cost over 10-year life }\end{array}$ & $\$ 33,070$ & $\$ 4480$ \\
$\begin{array}{l}\text { Total life cycle cost over 10 years } \\
\text { Total MWh savings over life cycle for the energy efficient } \\
\text { pump model }\end{array}$ & $\$ 309,316$ & $\$ 210,352$ \\
\begin{tabular}{l} 
Payback time \\
\hline
\end{tabular} & & $\$ 320,085$ \\
\hline
\end{tabular}


kilowatt peak installed. The installation of additional high-durability canopies to hold extra solar panels, changes electricity tariffs (see the 'Electricity cost and tariffs' section), and new government imposed no export and grid protection requirement resulted in an actual cost of $\$ 5.83$ per kilowatt peak installed. This combined with changes in the electricity tariff structure resulted in an increased modelled predicted payback time from 6 to 14 years. However, the large-scale renewable energy certificates (LGCs) have doubled in price from $\$ 35$ per megawatt hour in 2010 to $\$ 75$ per megawatt hour in 2015, which increases revenue and payback will decrease if all power generation wastage is eliminated. Regardless, the predicted financial savings for a 25year life of the solar PV system are still highly significant at $\$ 1.8 \mathrm{M}$ over the life of the system (Fig. 6).

Electricity cost and tariffs

The combined energy savings measured gradually lowered the peak power demand from the electricity grid by $46 \%$ between years 0 and 8 , and the Aquarium moved to a lower cost electricity tariff in year 7 . A huge increase of the grid connection fee, from $0.005 \%$ of the energy bill in year 0 to $26.5 \%$ in year 9 , offsets this benefit, increasing the expected payback period for the solar power system and (to a lesser extent) the HVAC system. The Aquarium paid more in electricity for half the power use in year 8 than in year 0 and the power cost would be doubled what it is today without the retrofit actions, well beyond affordability within current funding arrangements (Fig. 2).

Life cycle savings and $\mathrm{CO}_{2}$-e avoided

Figure 6 shows the cost of the main energy consuming elements against the carbon dioxide equivalent $\left(\mathrm{CO}_{2}\right.$-e) abatement for the life of the equipment. All groups except 'special machinery' are predicted to have significant financial benefits and $\mathrm{CO}_{2}$-e abatement over the life of the equipment, and the total $\mathrm{CO}_{2}$-e abatement for all measures is 1390 tonnes of $\mathrm{CO}_{2}$-e (excluding 'operational' group whose data is also included in the HVAC-related group) if the 'scope 2' emission factors are is used. If 'scope 2' and 'scope 3' emission factors are used, then the $\mathrm{CO}_{2}$-e abatement increases to 1614 tonnes of $\mathrm{CO}_{2}$-e (see the 'Energy use and costs data analysis' section). The baseline was adjusted by $286 \mathrm{MWh}$ to reflect additional pumping requirement for new or enhanced aquarium life support (see the 'Total energy consumption' section).

Non-financial and other benefits

The Aquarium exceeded the $230-\mathrm{kW}$ peak demand saving target that was part of the Ergon Demand Management Pilot Project (with $259 \mathrm{~kW}$ saved). In return, the Aquarium received a one off payment of $\$ 67,160$ (\$259.30/kW) by Ergon Energy in 2013 and was granted sustainability awards, positioning the Aquarium as an example for environmentally sustainable business practices (Queensland Tourism Awards 2012) (Ecotourism Australia 2012). The energy minimisation project helped to communicate conservation messages through education programmes and validated benefits and business cases for further initiatives.

\section{Discussion}

Relevance of energy use savings results for the buildings sector

The Aquarium reduced its energy intensity from $1625 \mathrm{MJ} \mathrm{m}^{-2}$ in year 0 to $773 \mathrm{MJ} \mathrm{m}^{-2}$ in year $8(973 \mathrm{MJ} \mathrm{m}$ -2 excluding solar generation). Using the 2011-2012 financial years, this compares with $2298 \mathrm{MJ} \mathrm{m}^{-2}$ for the Australian Institute of Marine Science (AIMS) in Townsville (Australian Government, Department of Climate Change and Energy Efficiency 2012); $3800 \mathrm{MJ} \mathrm{m}^{-2}$ for the average regional Queensland supermarket; and $1684 \mathrm{MJ} \mathrm{m}^{-2}$ for an average Australian hospital (Pitt and Sherry 2012). The National Australian Built Environment Rating System (NABERS) provides energy ratings and tools for commercial buildings to predict energy savings, but only for four types of commercial buildings: offices, shopping centres, data centres and hotels (New South Wales Office of Environment and Heritage 2016). A similar tool would have helped the Aquarium identify areas of poor performance, benchmark baselines and monitor progress.

Whole of life costs, impact of audits and access to knowledge in decision making

Major renovations rarely occur over the life of commercial buildings, and they are usually triggered by the equipment end of life or change to fitness of purpose. 


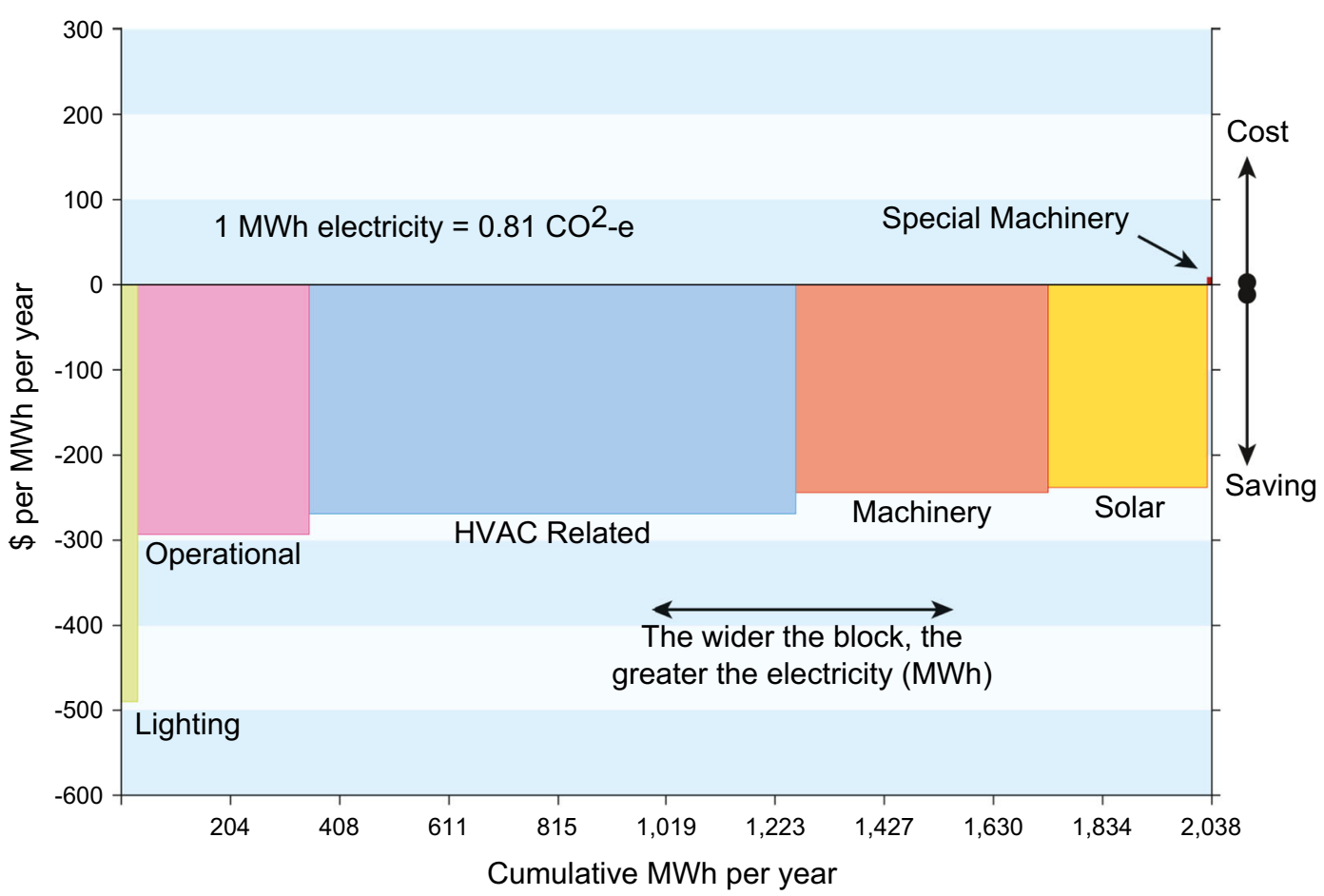

\begin{tabular}{|c|c|c|c|c|c|}
\hline & $\begin{array}{l}\text { Capital } \\
\text { Cost (\$) }\end{array}$ & $\begin{array}{l}\text { Payback } \\
\text { (years) }\end{array}$ & $\begin{array}{l}\text { Life cycle } \\
\text { savings (\$) }\end{array}$ & $\begin{array}{l}\text { MWh per year } \\
\text { avoided }\end{array}$ & $\begin{array}{l}\mathrm{CO}^{2} \text {-e per year } \\
\text { abated }\end{array}$ \\
\hline Lighting & 52,800 & 2.5 & 129,414 & 33 & 27 \\
\hline Machinery & 106,300 & 3 & $1,720,008$ & 471 & 382 \\
\hline Solar & $1,127,000$ & 14 & $1,781,088$ & 299 & 242 \\
\hline Operational & 6,500 & 0.3 & $2,339,757$ & 319 & 258 \\
\hline HVAC related $\dagger$ & 359,000 & 2 & $5,961,638$ & 910 & 737 \\
\hline Special Machinery & 25,400 & $\mathrm{n} / \mathrm{a}$ & -141 (cost) & 4 & 3 \\
\hline
\end{tabular}

Fig. 6 Marginal abatement cost analysis comparing energy use reduction measures with cost or saving per unit (MWh) of grid electricity use over the life of the category (y-axis). Accumulative grid electricity use avoided (or tonnes of carbon dioxide equivalent abated) is shown on the $\mathrm{x}$-axis. Special machinery is SCUBA compressor and reverse osmosis machine; dagger indicates replacement of HVAC with a like-for-like air-cooled system would have required increased efficiency by $14 \%$ to meet Australian

This represents $10 \%$ of all building construction (Pitt and Sherry 2014) but the buildings retrofit rate is only $2.2 \%$ per year (Ma et al. 2012). At the Aquarium, the end of life of infrastructure triggered the improvement of the building's energy performance, but only due to inhouse awareness of energy efficiency potential and whole of life costs gained through audits and networking. Prior to year 1, in-house knowledge on the connection between energy use and building design, standards for performance; HVAC figures compare savings over existing equipment in year 6; total replacement cost of HVAC would have a payback time of 6 years; baseline was adjusted (286 MWh added) to reflect additional machinery and load on the HVAC systems since year 1 (see the 'Total energy consumption' section for details). Data was generated and adapted from MACC BuilderPro ${ }^{\mathrm{TM}}$ software

maintenance and operation was lacking to drive the required strategic decisions. Pitt and Sherry (2014) document that stakeholders show little awareness of or interest in energy efficiency when considering retrofits. They also report large gaps in the quality, scope and accessibility of information on how sustainability relates to the built environment, leading to a low willingness to pay for energy-efficient options (Pitt and Sherry 2012), despite evidence that very low-energy retrofits of 
buildings can be economically attractive, sometimes even at net negative costs (Levine et al. 2007).

For the Aquarium, audits (despite their varying qualities against cost) were a fundamental stepping stone to achieve the desired outcomes. In this case study, the most expensive audits did not result in the most helpful outcomes, which emphasises the need for consumers to have access to detailed technical knowledge or assistance from accreditation schemes to assess energyefficient retrofit possibilities and audit providers (Department of Industry, Innovation and Science 2015). Redmond and Walker (2016) also found that economic returns can vary significantly for energy audits in Australia. The Aquarium case study may help other stakeholders invest with confidence in energyefficient infrastructure and consumers may maximise the benefits by specifying a detailed scope and desired outcomes, requiring supplier to specify standard audit methods and obtaining references from suppliers for their previous projects.

Maintenance of equipment, shift from design specifications and building heat loads

In this study, HVAC-related retrofit actions resulted in the greatest energy use savings, including actions to address poor maintenance. For buildings with centralised HVAC, there is no requirement to ensure that buildings are properly commissioned and maintained to guarantee design efficiency (Pitt and Sherry 2014), leading to significant yet avoidable energy inefficiencies. The Aquarium ensured that energy efficiencies were maximised by refining the BMS settings and operational processes, in collaboration with the designer, the installer and an independent quality controller. Pitt and Sherry (2014) report that the difference between good and poor commissioning of HVAC may represent up to double the rate of energy consumption.

The direct impact of glazing retrofits was not quantified in this study; however, other studies quote significant savings, with double insulated low-e glazing reducing HVAC electricity by 180-288 MJ m ${ }^{-2}$ year $^{-1}$ ( $\mathrm{Li}$ et al. 2015), or 'cool paints' on external walls and roofs reducing indoor cooling by $60 \%$ (Marino et al. 2015). Prior to year 1, air leaks caused significant wastage of energy, mainly through doors left open in summer for public movement. Once identified and addressed, subsequent savings were achieved but are still strongly influenced by staff behaviour and operational processes which is consistent with other studies (Azar and Menassa 2015).

\section{Thermal comfort, HVAC and BMS}

In this study, a $1.5^{\circ} \mathrm{C}$ rise in indoor temperature significantly reduced power consumption (by $13 \%$ in year 1 ) with no significant change in survey respondent's assessment of comfort and no significant change in worker's assessment of their own productivity. This is comparable to studies of Sydney, Melbourne and Brisbane offices where an average of $6 \%$ power use was saved for every $1{ }^{\circ} \mathrm{C}$ increase in indoor temperature in summer (Roussac et al. 2011). Another study found an average thermal comfort level of $26.4{ }^{\circ} \mathrm{C}$ for two Indian cities, which is warmer than the current Indian standard upper limit of $26^{\circ} \mathrm{C}$ (Indraganti et al. 2014).

Prior to 2007 , the Aquarium was maintained at a relatively low temperature $\left(23^{\circ} \mathrm{C}\right)$ which did not take into account visitors' adaptation to the tropical conditions outside (which may be more than $10{ }^{\circ} \mathrm{C}$ higher) and modern thermal comfort expectations for the indoor environment. Nicol (2004) argues that thermal comfort is affected by outdoor temperature, and takes into account the adaptive thermal comfort model, and other authors report that expectations appear to be based on recent experiences (Luo et al. 2016). Therefore, it is important to periodically review indoor temperature set-points against current standards and models. The efficacy of an Ergon Energy initiative encouraging the use of higher indoor set-point $\left(25^{\circ} \mathrm{C}\right)$ or similar community campaigns in North Queensland remains unquantified. 'Energy cost saving' is considered an important driver to tolerate high indoor temperatures if those enduring the higher temperatures can see cost benefits flow on to them, and can be a more important factor than occupant thermal comfort and productivity when deciding on indoor temperature set-points (Lakeridou et al. 2014; Boldero 2013). It would be useful to undertake further tests at the Aquarium to determine whether the indoor temperature set-points could be further increased (and determine comfort thresholds) up to the current applicable Australian standards $\left(26^{\circ} \mathrm{C}\right)$. Since HVAC is responsible for around $50-70 \%$ of energy use in buildings, this measure represents a high potential for energy use reductions with minimal cost. Further case studies are needed to determine if expectation management can help to foster 
thermal comfort adaptability in the tropics, and maximise the potential energy saving for HVAC use.

Innovative and site-specific BMS control of HVAC with integrated TES and solar PV power can produce significant efficiencies with minimal cost, to the extent that it delayed the need for electrical battery power storage at the Aquarium. The Aquarium uses the Reef Tank to store chilled water. Although chilled water energy is not discharged to a different system, like a traditional TES system, the cooling requirement is brought forward by chilling the tank lower than the optimal set-point. Thus, the cooling capacity is effectively stored in the system which maintains the temperature below or at the optimal set-point for longer thereby negating the need for the capacity later. Not only does this help to minimise PV generation wastage, it also helps to minimise peak demand. The methods in this study could be similarly applied to hotels with heated swimming pools, public swimming pools and other aquariums. A larger TES system used specifically to store energy from surplus solar PV may provide a lower cost option against electrical battery storage. Historically, TES systems have been used only to manage peak demand to minimise the cost of power, where there are time of use and demand tariffs.

\section{Most significant actions and indirect benefits}

The benefits of one conservation measure against the others are not always quantifiable due to (a) simultaneous changes and absence of separate power use logging on all components and (b) the significant and complex non-financial factors involved. A HVAC retrofit is a highly effective action to realise large reductions in energy consumption consistent with the findings of others (Carbon Trust Australia 2010). Optimization of energy use using a BMS is a low-cost and flexible tool to minimise wastage of power use and power generation, and operational changes stand out as a highly efficient measure to reduce energy use, with an immediate outcome and no financial cost, and should be considered seriously alongside hi-tech measures.

As they are difficult to quantify or predict for the purpose of a business case, many retrofit actions had indirect benefits that were either underestimated or not contemplated at the outset. For instance, the energyefficient items tended to be of higher quality and durability than non-energy efficient equipment (lower maintenance requirement), reduced transport costs, waste disposal and administration for replacement equipment. The new ability to always maintain an optimum temperature in the Aquarium's Coral Reef Exhibit (the world's largest living coral reef aquarium and principal asset of the Aquarium) was a highly significant benefit. Prior to year 6 , the temperature would frequently drop below a critical threshold in the hot summer months. As a consequence, corals would sporadically experience the potentially lethal 'coral bleaching' due to heat stress. The massive reduction in power consumption also allowed the entire site to be linked to the emergency standby diesel generators, where previously only limited items could be connected.

\section{Renewable energy}

Despite non-advantageous site-specific factors and changes to the electricity tariff structure since year 0 , the whole of life financial benefits for the Aquarium's solar PV system is predicted to be significant. Other sites may not have these costs, and hence payback times may be much lower also considering the falling cost of solar systems and emerging storage technologies. Despite these proven advantages and excellent geographical conditions for solar power technology, the number of large commercial rooftop systems in Queensland remains small (Garnaut 2011) which provides significant potential for new solar energy installations. It is important to consider the entire life cycle and environmental costs of PV power compared to electricity produced from coal. The environmental cost of PV systems over their entire lifecycle is an order of magnitude lower than a coal power station in terms of greenhouse gas emissions (Peng et al. 2013; Epstein et al. 2011) and other reduced environmental and human impacts associated with non-renewable energy sources (Spath et al. 1999). The successful application of the BMS combined with the solar PV has highlighted the opportunity to expand the PV system at the Aquarium if a larger TES is added, delaying the need for electrical battery storage.

Investment patterns and business growth

Substantial reductions in global carbon dioxide emissions will require large changes in investment patterns (Levine et al. 2007). The energy reductions achieved by the Aquarium were only possible through a major shift in investment patterns and procurement strategies. With 
limited evidence to support business models and predictions, considerable negotiations within the procurement process were required due to perceived risk. Thus, a lack of energy efficiency regulations, knowledge, time and confidence to pursue the energy efficient options may easily result in lost opportunities for savings. Even within the Australian government, operations which use 22 million GJ year ${ }^{-1}$ of energy (Australian Government, Department of Climate Change and Energy Efficiency 2012) and occupies 32\% of Australian commercial buildings stock (Energy Efficiency Council 2011) further integrating environmental sustainability in the procurement process could generate significant savings (The Auditor-General 2015). An average energy efficiency improvement in buildings of less than $3 \%$ would free up $\$ 10$ million a week to be invested in other parts of the Australian economy, and reduce the negative and social costs of greenhouse gas emissions in the process (Pitt and Sherry 2014). The results achieved at the Aquarium show the potential benefits if similar energy saving initiatives were undertaken on a national scale, if facilitated by a clear mandate, clear process and timely access to funding (Energy Efficiency Council 2011).

The Aquarium was able to grow its business despite the disruptions that the refurbishments created, and visitor numbers to the Aquarium were at their highest in 15 years in 2012 (year 7) and continue to rise. Part of the move towards a more sustainable business model has been to place education at the centre of all energy conservation actions, which appears to foster tolerance for the difficult aspects of the changes and maximise the benefits of the changes.

Future actions

Energy consumption increased significantly in the category 'other' from year 0 to year 8 (Fig. 3). This category will be targeted to reduce and manage energy use. Additional energy use reduction measures include (a) additional solar PV combined with additional TES and other energy storage solutions; (b) further increases in temperature set-points with a targeted communication campaign; (c) further measures to reduce heat load on the building such as the use of hi-tech material to shade the large outside aquariums; (d) computerised control of the compressor driven 'wave machine' to maximise efficiency; (e) investigation of non-solar renewable energies such as tidal and wind; (f) energy recovery systems; (g) further modifications to filtration system to maximise efficiency; and (i) further utilisation of the BMS to maximise efficient use of power.

\section{Conclusions}

This case study shows that it is possible to adopt very low-cost energy saving measures (such as indoor temperature adjustments and better maintenance of HVAC) in a commercial building with no significant negative effects on comfort or employee productivity. If similar measures were adopted nationwide, millions of dollars may be liberated for the Australian economy. This case study also shows that capital investment in energyefficient critical infrastructure such as HVAC (particularly where equipment and infrastructure nears the end of its life) can have short payback times and high direct and indirect benefits relative to costs. Here, the most effective measures were as follows: manipulation of indoor temperature and energy wasting behaviours, investment in high-quality and low-energy equipment (pumps and lights), upgrade and fine-tuning of the BMS-controlled HVAC system with integrated TES, modification of the building envelope (double glazing, reflective roof coating and minimisation of building leaks) and generation of renewable energy. This study is important as it demonstrates that a BMS can be used to control HVAC with integrated TES to optimise and store solar PV and also avoid PV energy wastage thereby avoiding or delaying the need for electrical battery storage. These measures are relevant to many medium to large commercial buildings.

The experience of Reef HQ Aquarium described in this study illustrates the positive impacts of reducing greenhouse gas emissions and simple ways to achieve a more environmentally responsible business model, through an energy-efficient building retrofit. An increased knowledge of the effect of building design, maintenance, equipment efficiency, whole of life cycles and equipment quality on annual energy costs may also increase a willingness to pay for high-quality energyefficient products.

Acknowledgments The data collection in this case study was funded by the GBRMPA with two exceptions: Ergon Energy funded two energy audits and an M\&V report for the Demand Management Pilot programme. The authors would like to thank Fred Nucifora, Reef HQ Aquarium Director, for his inspiring leadership, GBRMPA senior management for their support in 
decision making and Reef HQ Aquarium staff for their commitment to energy minimisation programs. Thanks also go to Adam Smith, Mike Tarrant, Tyrone Ridgway and Ashley Frisch for their valuable comments on the paper. Thanks to Marcus Thyer from Cave Image Manipulation for assistance with figures. Thanks to the following individuals and organisations who took a keen interest in helping Reef HQ Aquarium to achieve the best possible results: Townsville City Council, Peak ARE Pty Ltd., NQ Control Services, Tropical Energy Solutions Pty Ltd., Stowe Australia Pty Ltd. and Warren Applegate, Ian McGregor and Neil Horsley (Ergon Energy).

Author contributions S.Thy. (Reef HQ Aquarium Technical Operations Manager and capital projects manager) designed the study and implemented the projects, and collected and analysed the data. C.M. designed the TES, HVAC and BMS and was engaged by Ergon Energy to carry out the M\&V study for the Ergon Energy Demand Management Pilot Programme. S.Thy. and S. Tho. drafted the manuscript. M.R. carried out the statistical analysis and contributed to the design for the thermal comfort study. All authors edited the manuscript and gave final approval for publication.

\section{Compliance with ethical standards}

Conflict of interest The authors declare that they have no conflict of interest.

Open Access This article is distributed under the terms of the Creative Commons Attribution 4.0 International License (http:// creativecommons.org/licenses/by/4.0/), which permits unrestricted use, distribution, and reproduction in any medium, provided you give appropriate credit to the original author(s) and the source, provide a link to the Creative Commons license, and indicate if changes were made.

\section{References}

Aljami, A. (2012). Energy audit of an educational building in a hot summer climate. Energy and Buildings, 47(April 2012), 122-130.

American Society of Heating Refrigeration and Air-conditioning Engineers (ASHRAE). (2014). ASHRAE Guideline 14-2014. Atlanta, GA: ASHRAE.

Ardente, F., Beccali, M., Cellura, M., \& Mistretta, M. (2011). Energy and environmental benefits in public buildings as a result of retrofit actions. Renewable and Sustainable Energy Reviews, 15(1), 460-470.

Australian Government, Department of Climate Change and Energy Efficiency. (2012). Energy use in Australian government operations 2009-10. Canberra: Department of Climate Change and Energy Efficiency.

Australian Sustainable Built Environment Council (ASBEC). (2008). The second plank — building a low carbon economy with energy efficient buildings. Victoria: Australian
Sustainable Built Environment Council Climate Change Task Group.

Azar, E., \& Menassa, C. C. (2015). Evaluating the impact of extreme energy use behaviour on occupancy interventions in commercial buildings. Energy and Buildings, 97(15 June 2015), 205-218.

Biswas, W. K. (2014). Carbon footprint and embodied energy consumption assessment of building construction works in Western Australia. International Journal of Sustainable Built Environment, 3(2), 179-186.

Boldero, J. M. (2013). Can psychological and practice theory approaches to environmental sustainability be integrated? Environment and Planning A, 45, 2535-2538. doi:10.1068 /a130196c.

Bureau of Meteorology (BOM) (2015). http://www.bom.gov.au. Accessed 13 September 2015.

Carbon Trust Australia. (2010). Australian Carbon Trust report: commercial buildings emissions reduction opportunities. Australia: ClimateWorks.

Colmenar-Santos, A., Noemí Terán de Lober, L., Borge-Diez, D., \& Castro-Gil, M. (2013). Solutions to reduce energy consumption in the management of large buildings. Energy and Buildings, 56(January 2013), 66-77.

Department of Industry and Science. (2015). 2015 Australian energy update. Canberra: Commonwealth of Australia http://www.industry.gov.au/Office-of-the-ChiefEconomist/Publications/Documents/aes/2015-australianenergy-statistics.pdf. accessed 15 September 2015.

Department of Industry, Innovation and Science (2015). Energy. h t t p : / industry.gov. au/Energy/Energyinformation/Pages/default.aspx. Accessed 13 September 2015.

Department of the Environment, Commonwealth of Australia. (2014). National greenhouse accounts factors-August 2015. Canberra: Department of the Environment https://www.environment.gov.au/climatechange/greenhouse-gas-measurement/publications/nationalgreenhouse-accounts-factors-aug-2015. Accessed 15 September 2015.

Ecotourism Australia (2012). http://www.ecotourism.org.au/ecoexperiences/green-travel-guide/reef-hq-aquarium. Accessed 9 September 2015.

Efficiency Valuation Organisation (EVO) (2012). International performance measurement and verification protocol (IPMVP), concepts and options for determining energy and water savings Volume 1. http://evo-world.org/en. Accessed 15 September 2015.

Energy Efficiency Council. (2011). National Framework for sustainable government office buildings, guidance paper on energy efficiency retrofits and energy performance contracting. Canberra: Australasian Procurement and Construction Council Inc. http://www.eec.org.au. Accessed 15 September 2015.

Epstein, P. R., Buonocore, K. E., Eckerle, K., Hendryx, M., Stout III, B. M., Heinberg, R., et al. (2011). Full cost accounting for the life cycle of coal. Annals of the New York Academy of Sciences, Ecological Economics Reviews, 1219, 73-98. doi:10.1111/j.1749-6632.2010.05890.x.

Fiaschi, D., Bandinelli, R., \& Conti, S. (2012). A case study for energy issues of public buildings and utilities in a small municipality: investigation of possible improvements and 
integration with renewables. Applied Energy, 97(September 2012), 101-114.

Frontier Economics Pty. Ltd. (2015). Electricity market forecasts: 2015. In A report prepared for the Australian Energy Market Operator (AEMO), Australia. Melbourne: Frontier Economics Pty. Ltd. https://www.aemo.com.au. Accessed 15 September 2015.

Garnaut, R. (2011). Garnaut climate change review-Update 2011, update paper eight: transforming the electricity sector. Commonwealth of Australia. http://www.garnautreview.org. au/update-2011/update-papers/up8-transforming-electricitysector.pdf. Accessed 12 September 2015.

Great Barrier Reef Marine Park Authority. (2007). Climate change action plan 2007-2012, Townsville. Great Barrier Reef Marine Park Authority: Australia http://www.gbrmpa.gov. $\mathrm{au} / \mathrm{managing}$-the-reef/threats-to-the-reef/climatechange/marine-park-management/climate-change-actionplan.

Green Energy Markets (2016). Green energy markets. http://greenmarkets.com.au . Accessed 24 Feb 2016.

Huizanga, C. (2010). ASHRAE thermal comfort tool, version 2.0.03. California: centre for built environment. Berkeley: University of California.

Indraganti, M., Ooka, R., Rijal, H. B., \& Brager, G. S. (2014). Adaptive model of thermal comfort for offices in hot and humid climates in India. Building and Environment, 74(April 2014), 39-53.

International Organization for Standardization (ISO). (2011). ISO 50001:2011 energy management systems-requirements with guidance for use. Geneva: ISO.

International Organization for Standardization (ISO). (2014). ISO 17741:2016 general technical rules for measurement, calculation and verification of energy savings of projects. Geneva: ISO.

Kekäläinen, P., et al. (2010). Effect of reduced summer indoor temperature on symptoms, perceived work environment and productivity in office work. Intelligent Buildings International, 2, 251-266.

Lakeridou, M. N., Ucci, M., \& Marmot, A. (2014). Imposing limits on summer set-points in UK air-conditioned offices: a survey of facility managers. Energy Policy, 75(December 2014), 354-368.

Levine, M. D., Ürge-Vorsatz, K., Blok, L., Geng, D., Harvey, S., Lang, G., et al. (2007). Residential and commercial buildings. In B. Metz, O. R. Davidson, P. R. Bosch, R. Dave, \& L. A (Eds.), Climate change 2007: mitigation, contribution of working group III to the fourth assessment report of the intergovernmental panel on climate change. UK and New York: Cambridge University Press.

Li, C., Tan, J., Chow, T.-T., \& Qiu, Z. (2015). Experimental and theoretical study on the effect of window films on building energy consumption. Energy and Buildings, 102(September 2015), 129-138.

Luo, M., de Dear, R., Ji, W., Bin, C., Lin, B., Ouyang, Q., \& Zhu, Y. (2016). The dynamics of thermal comfort expectations: the problem, challenge and implication. Building and Environment, 95(January 2016), 322-329.

Ma, Z., Cooper, P., Daly, D., \& Ledo, L. (2012). Existing building retrofits: methodology and state-of-the-art. Energy and Buildings, 55(15 may 2016), 889-902.
Marino, C., Minichiello, F., \& Bahnfleth, W. (2015). The influence of surface finishes on the energy demand of HVAC system for existing buildings. Energy and Buildings, 95(15 May 2015), 70-79.

Markis, T., \& Paravantis, J. A. (2007). Energy conservation in small enterprises. Energy and Buildings, 39(4), 404-415.

New South Wales Office of Environment and Heritage, (2016). NABERS (National Australian Built Environment Rating System). http://www.nabers.gov.au. Accessed 6 June 2016.

Nicol, F. (2004). Adaptive thermal comfort standards in the hothumid tropics. Energy and Buildings, 36(7), 628-637.

Peng, J., Lu, L., \& Yang, H. (2013). Review on life cycle assessment of energy payback and greenhouse gas emission of solar photovoltaic systems. Renewable and Sustainable Energy Reviews, 19(March 2013), 255-274.

Perez-Lombard, L., Ortiz, J., \& Pout, C. (2008). A review on buildings energy consumption information. Energy and Buildings, 40(3), 394-398.

Pitt\&Sherry (2012). Baseline energy consumption and greenhouse gas emissions in commercial buildings in Australia-Part 1 -report. Department of Climate Change and Energy Efficiency. http://www.pittsh.com.au/assets/files/CE\%20 Showcase/Commercial_buildings_baseline_study.pdf. Accessed 15 September 2015.

Pitt\&Sherry. (2014). National Energy Efficient Building Project for the National Strategy on energy efficiency. South Australia: Department of State Development http://www. pittsh.com.au/assets/files/Projects/NEEBP-final-reportNovember-2014.pdf. Accessed 15 September 2015.

Queensland Tourism Awards, 2012. Queensland Tourism Awards. http://www.queenslandtourismawards.com.au/results/2012winners. Accessed 9 September 2015.

Rahman, M. M., Rasul, M. G., \& Khan, M. M. K. (2010). Energy conservation measures in an institutional building in subtropical climate Australia. Applied Energy, 87(10), 2994 3004.

Redmond, J., \& Walker, B. (2016). The value of energy audits of SMEs: an Australian example. Journal of Energy Efficiency, 9(5), 1053-1063.

Roussac, C. A., Steinfeld, J., \& de Dear, R. (2011). A preliminary evaluation of two strategies for raising indoor air temperature setpoints in office buildings. Architectural Science Review, 54(2) doi:10.1080/00038628.2011.582390. Accessed 15 September 2015.

Rupp, R. F., Vásquez, N. G., \& Lamberts, R. (2015). A review of human thermal comfort in the built environment. Energy and Buil,dings, 105(15 October 2015), 178-205.

Rysanek, A. M., \& Choudhary, R. (2013). Optimum building energy retrofits under technical and economic uncertainty. Energy and Buildings, 57(February 2015), 324-337.

Saddler, H. (2015). Power down II-the continuing decline in Australia's electricity demand. Canberra: Australia Institute http://www.tai.org.au/content/power-down. Accessed 15 September 2015.

Sehar, F., Pipattanasomporn, M., \& Rahman, S. (2016). An energy management model to study energy and peak power savings from PV and storage in demand responsive buildings. Applied Energy, 173(July 2016), 406-417.

Spath, P. L., Mann, M. K., \& Kerr, D. R. (1999). Life cycle assessment of coal-fired power production. U.S.: National 
Renewable Energy Laboratory http://www.nrel. gov/docs/fy99osti/25119.pdf. Accessed 15 September 2015.

Standards Australia. (2014). AS/NZS 3598:2014 (set). In Energy Audit series. Sydney: SAI Global Limited.

StataCorp. (2013). Statistica 13 package. College Station: StataCorp LP.

Steinfeld, J., Bruce, A., \& Watt, M. (2011). Peak load characteristics of Sydney office buildings and policy recommendations for peak load reduction. Energy and Buildings, 43(9), 2179-2187.

Stoppato, A. (2008). Life cycle assessment of photovoltaic electricity generation. Energy, 33(2), 224-232.

Sun, Y., Wang, S., Xiao, F., \& Gao, D. (2013). Peak load shifting control using different cold thermal energy storage facilities in commercial buildings: a review. Energy Conversation and Management, 71(July 2013), 101-114.

The Auditor-General. (2015). Limited tender procurement ANAO report no. 48 2014-15 performance audit. Australian National Audit Office: Canberra https:/www.anao.gov.
au/sites/g/files/net616/f/ANAO_Report_2014-2015_48.pdf. Accessed 15 September 2015.

Vivid Economics. (2013). Energy efficiency and economic growth. London: Vivid Economics http://www.climateinstitute.org. au. Accessed 15 September 2015.

Wang, X., \& Dennis, M. (2015). Influencing factors on the energy saving performance of battery storage and phase change cold storage in a PV cooling system. Energy and Buildings, 107(August 2015), 84-92.

Woo, J., \& Menassa, C. (2014). Virtual retrofit model for aging commercial buildings in a smart grid environment. Energy and Buildings, 80(September 2014), 424-435.

Xydis, G., \& Mihet-Popa, L. (2016). Wind energy integration via residential appliances. Energy Efficiency. doi:10.1007 /s12053-016-9459-2.

Yu, Z. J., Huang, G., Haghighat, F., Li, H., \& Zhang, G. (2015). Control strategies for the integration of thermal energy storage into buildings: state-of-the-art review. Energy and Buildings, 106(November 2015), 203-215. 